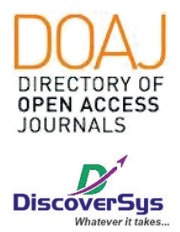

Published by DiscoverSys

\section{Karakteristik profil pasien urtikaria akut di poliklinik kulit dan kelamin Rumah Sakit Umum Pusat (RSUP) Sanglah periode Oktober 2017- 2018}

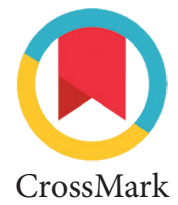

\author{
Gede Mahadika Pradipta Atmaja, ${ }^{1 *}$ Nyoman Suryawati, ${ }^{2}$ Luh Made Mas Rusyati ${ }^{2}$
}

\section{ABSTRACT}

Background: Acute urticaria is a skin disorder that is often encountered that can cause redness to respiratory obstruction so that emergency emergencies and urticaria lesions that last more than 72 hours are indicative of hospitalized patients. This study aims to describe the characteristics of acute urticaria at Dermato-Venerology Polyclinic, Sanglah General Hospital during October 2017-2018 period.

Methods: A cross-sectional study was conducted using secondary data from medical records of patients with urticaria in Sanglah General Hospital in the October 2017-2018 period. Data retrieval was taken by the Total Sampling method. Distribution of research variables namely, gender, age, genetic, causative factors, were collected. Data analysis is described in the form of tables and narratives using SPSS version 20 for Windows.

Results: The results showed that there were 23 acute urticaria patients in this study, the age of the most research samples was in the Adult age category with a large percentage of $60.87 \%$, the most genderbased study sample was female gender with a percentage of $78.3 \%$, research genetic samples most of them are in the absence of genetics, with a percentage of $91.3 \%$, the work of most research samples in housewives with a percentage of $34.8 \%$, the most common cause of acute urticaria is in food allergies with a percentage of $56.5 \%$.

Conclusion: The incidence of acute urticaria is most common in adulthood, female sex, housewives, and food allergies.
${ }^{1}$ Mahasiswa Pendidikan Dokter, Fakultas Kedokteran, Universitas Udayana, Denpasar, Bali, Indonesia ${ }^{2}$ Departemen Kulit dan Kelamin, Fakultas Kedokteran, Universitas Udayana, RSUP Sanglah, Denpasar, Bali, Indonesia

\section{*Korespondensi:}

Gede Mahadika Pradipta Atmaja; Mahasiswa Pendidikan Dokter, Fakultas Kedokteran, Universitas Udayana, Denpasar, Bali, Indonesia; mahadikapradipta4@gmail.com

Diterima: 30-03-2019

Disetujui: 16-08-2019

Diterbitkan: 01-12-2019

Keywords: acute urticaria, characteristics, profile, polyclinic

Cite This Article: Atmaja,G.M.P., Suryawati,N., Rusyati, L.M.M. 2019. Karakteristik profil pasien urtikaria akut di poliklinik kulit dan kelamin Rumah Sakit Umum Pusat (RSUP) Sanglah periode Oktober 2017- 2018. Intisari Sains Medis 10(3): 584-587. D0I: 10.15562/ism.v10i3.469

\title{
ABSTRAK
}

Latar belakang: Urtikaria akut merupakan kelainan kulit yang sering dijumpai dimana dapat menyebabkan kemerahan hingga obstruksi nafas sehingga merupakan kegawat daruratan dan lesi urtikaria yang bertahan lebih dari 72 jam merupakan indikasi pasien rawat inap. Penelitian ini bertujuan untuk mengetahui gambaran karakteristik Urtikaria Akut pada poliklinik kulit dan kelamin di RSUP Sanglah selama periode Oktober 2017-2018.

Metode: Penelitian potong lintang dilakukan menggunakan data sekunder dari rekam medis pasien urtikaria di RSUP Sanglah pada periode Oktober 2017-2018. Pengambilan data di ambil dengan metode Total Sampling. Distribusi variabel penelitian yaitu jenis kelamin, umur, genetik, faktor penyebab. Analisis data di paparkan dalam bentuk tabel dan narasi yang dikerjakan menggunakan SPSS versi 20 untuk Windows
Hasil: Hasil penelitian menunjukan terdapat 23 pasien Urtikaria akut pada penelitian ini umur sampel penelitian terbanyak yaitu pada kategori umur Dewasa dengan besar presentase 60,87\%, perdasarkan jenis kelamin sampel penelitian terbanyak yaitu pada jenis kelamin perempuan dengan besar persentase $78,3 \%$, sampel genetik penelitian terbanyak ada pada tidak adanya genetik, dengan persentase sebesar $91,3 \%$, pekerjaan sampel penelitian terbanyak pada ibu rumah tangga dengan presentase 34,8\%, penyebab urtikaria akut terbanyak yaitu pada alergi makanan dengan persentase $56,5 \%$.

Kesimpulan: Kejadian urtikaria akut paling banyak terjadi pada usia dewasa, jenis kelamin perempuan, ibu rumah tangga, dan alergi makanan.
Kata kunci: urtikaria akut, karakteristik, profil, poliklinik

Cite This Article: Atmaja,G.M.P., Suryawati,N., Rusyati, L.M.M. 2019. Karakteristik profil pasien urtikaria akut di poliklinik kulit dan kelamin Rumah Sakit Umum Pusat (RSUP) Sanglah periode Oktober 2017- 2018. Intisari Sains Medis 10(3): 584-587. D0I: 10.15562/ism.v10i3.469

\section{PENDAHULUAN}

Urtikaria merupakan respon kulit dengan batas yang tegas, terjadi pada epidermis superfisial, berupa urtika, yaitu lesi eritematous dan menonjol 1-2 mm sampai beberapa jam disertai rasa gatal yang hebat. ${ }^{1}$ Urtikaria diklasifikasikan menurut lamanya, yaitu Urtikaria akut dan Urtikaria kronis. ${ }^{2}$ Urtikaria dapat diklasifikasikan berdasarkan durasi dan faktor pencetus. Berdasarkan 
durasi, Urtikaria dapat diklasifikasikan menjadi Urtikaria akut ( $<6$ minggu) dan Urtikaria kronis (>6 minggu). ${ }^{2}$

Urtikaria harus dibedakan dengan kondisi atau penyakit lain yang menimbulkan peninggian kulit atau angioedema, seperti reaksi anafilaksis, sindrom auto- inflamasi, dan hereditary angioedema. Urtikaria umumnya disertai dengan gatal-gatal, meskipun Urtikaria adalah kondisi yang jinak, pasien merasa frustasi, karena kronisitas dan kecenderungannya untuk kambuh. Urtikaria merupakan reaksi alergi yang dapat mengancam jiwa. ${ }^{3}$ Diagnosis dibuat berdasarkan pemeriksaan klinis. Itu mempengaruhi 20\% populasi umum. Pengobatan lini pertama Urtikaria mencakup penggunaan $\mathrm{H}$-lanti-histamin. Namun, terapi lain dapat digunakan. ${ }^{4}$ Penatalaksanaan dan manajemen berfokus pada pencegahan, menghindari pemicu, dan mengobati gatal dan peradangan yang menyertai kondisi ini. ${ }^{4}$

Tabel 1 Karakteristik responden dengan Urtikaria Akut di RSUP Sanglah, Bali, Indonesia

\begin{tabular}{|c|c|c|}
\hline Variabel & Frekuensi $(\mathrm{N}=23)$ & Persentase (\%) \\
\hline \multicolumn{3}{|l|}{ Usia (Tahun) } \\
\hline $1-10$ & 5 & 21,74 \\
\hline $11-19$ & 1 & 4,35 \\
\hline $20-65$ & 14 & 60,87 \\
\hline$>65$ & 3 & 13,04 \\
\hline \multicolumn{3}{|l|}{ Jenis Kelamin } \\
\hline Laki-laki & 5 & 21,7 \\
\hline Perempuan & 18 & 78,3 \\
\hline \multicolumn{3}{|l|}{ Genetik } \\
\hline Ada & 2 & 8,7 \\
\hline Tidak & 21 & 91,3 \\
\hline \multicolumn{3}{|l|}{ Pekerjaan } \\
\hline Guru SD & 1 & 4,3 \\
\hline Pensiunan & 1 & 4,7 \\
\hline Ibu Rumah Tangga & 8 & 34,8 \\
\hline Pegawai Swasta & 3 & 13,0 \\
\hline PNS & 1 & 4,3 \\
\hline Pelajar & 6 & 26,1 \\
\hline Wiraswasta & 2 & 8,7 \\
\hline Tidak ada & 1 & 4,3 \\
\hline \multicolumn{3}{|l|}{ Penyebab urtikaria } \\
\hline Obat & 2 & 8,7 \\
\hline Makanan & 14 & 60,9 \\
\hline Cuaca & 5 & 21,7 \\
\hline Spora & 1 & 4,3 \\
\hline Debu & 1 & 4,3 \\
\hline
\end{tabular}

Dari uraian latar belakang, peneliti ingin mengetahui prevalensi dan karakteristik pasien urtikaria akut di poli Kulit dan Kelamin RSUP Sanglah. Karakteristik yang dimaksud mencakup karakteristik utrtikaria akut berdasarkan umur, pekerjaan, jenis kelamin, pekerjaan, genetik, maupun pola penyebabnya.

\section{METODE}

Penelitian ini menggunakan desain potong lintang yang berasal dari data sekunder rekam medis pasien urtikana akut yang mendapat perawatan di Poliklinik Kulit dan Kelamin RSUP Sanglah Denpasar, periode Oktober 2017-2018 menggunakan teknik total sampling. Urtikaria akut didefinisikan sebagai reaksi gatal atau alergi pada kulit yang terjadi pada waktu $<6$ minggu dimana ditandai dengan munculnya bercak kemerahan, reaksi vaskuler seperti gatal-gatal atau biduran, atau rasa terbakar, dimana umumnya menghilang 1-24 jam. Ada atau tidaknya urtikaria akut berdasarkan diagnosis kerja dari data rekam medis pasien. Hasil ukur yaitu positif terkena urtikaria akut dan negatif terkena urtikaria akut dengan skala nominal. Parameter demografis yang diukur pada penelitian ini adalah jenis kelamin, umur, genetik, dan faktor penyebab. Faktor penyebab adalah beberapa faktor lingkungan, reaksi alergi akibat memakan seafood atau makanan laut terutama kerang, coklat, kacang ada juga reaksi yang disebabkan oleh suhu, terkena bulu hewan, spora jamur, serbuk bunga dan lain sebagainya dalam sekala nominal.

Pengambilan dan pengumpulan data sekunder diperoleh dari rekam medis di Rumah Sakit Umum Pusat (RSUP) Sanglah dengan Ethical Clearance (EC) dengan nomor EC: 2463/UN14.2.2.VII.14/ LP/2018 untuk memproses di buku registrasi Poli Kulit Kelamin RSUP Sanglah Denpasar. Pengambilan data rekam medis seluruh pasien urtikaria akut pada periode Oktober 2017-2018 di Poliklinik Kulit dan Kelamin RSUP Sanglah Denpasar diinput ke dalam program aplikasi SPSS versi 20. Data yang diperoleh kemudian ditampilkan dalam bentuk frekuensi dan persentase serta penjelasan secara naratif.

\section{HASIL}

Berdasarkan penelitian yang telah dilakukan telah diperoleh sebanyak 23 sampel yang memenuhi kriteria penelitian. Tabel 1 menunjukkan kelompok Umur dari sampel untuk kategori umur dimana anak-anak (1-10 tahun) didapatkan sebanyak 5 sampel (21.74\%). Kategori umur Remaja (11-19 tahun) di dapatkan 1 sampel penelitian 
Tabel 2 Perbandingan kelompok urtikaria terhadap penyebab urtikaria

\begin{tabular}{|c|c|c|c|c|c|}
\hline \multirow[b]{2}{*}{ Penyebab } & \multicolumn{2}{|c|}{ Urtikaria ( $\mathbf{N = 2 3 )}$} & \multirow{2}{*}{$\begin{array}{c}\text { Prevalensi } \\
\text { Urtikaria }\end{array}$} & \multirow{2}{*}{$\begin{array}{c}\text { Prevalensi Non- } \\
\text { Urtikaria }\end{array}$} & \multirow[b]{2}{*}{ PR } \\
\hline & lya & Tidak & & & \\
\hline Obat & 2 & 2 & 0,5 & 0,1 & 5,8 \\
\hline Makanan & 14 & 6 & 3,5 & 0,3 & 13,4 \\
\hline Cuaca & 5 & 4 & 1,25 & 0,2 & 7,2 \\
\hline Spora & 1 & 7 & 0,25 & 0,3 & 0,8 \\
\hline Debu & 1 & 4 & 0,25 & 0,2 & 1,4 \\
\hline
\end{tabular}

PR: prevalensi rasio

dengan presentase sebesar (4,3\%). Kategori umur Dewasa di dapatkan 14 sampel penelitian dengan presentase $(60,87 \%)$ dan Kategori umur Lanjut Usia didapatkan 3 sampel dengan persentase (13,04\%).

Berdasarkan jenis kelaimin hasil penelitian menunjukkan terdapat 5 sampel penelitian $(21,7 \%)$ untuk jenis kelamin laki-laki, 18 sampel penelitian $(78,3 \%)$ untuk jenis kelamin perempuan. Hasil penilaian genetik sampel penelitian untuk yang memiliki genetik diperoleh 2 frekuensi penelitian $(8,7 \%)$, Untuk yang tidak memiliki genetik diperoleh 21 frekuensi penelitian (91,3\%).

Berdasarkan Pekerjaan dari sampel untuk pekerjaan guru SD di dapatkan 1 sampel penelitian ( 4,3\%), untuk pensiunan di dapatkan 1 sampel penelitian (4.7\%), pasien ibu rumah tangga di dapatkan 8 sampel penelitian (34.8\%), untuk pegawai swasta di dapatkan 3 sampel penelitian (13.0), pasien PNS 1 sampel penelitian (4.3\%), pelajar di dapatkan 6 sampel penelitian $(26,1 \%)$, Pasien wiraswasta 2 sampel penelitian (8.7), dan yang untuk tidak memiliki pekerjaan sampel penelitian 1 presentase $(4,3 \%)$ (Tabel 1 ).

Berdasarkan Penyebab Urtikaria Akut untuk yang memiliki alergi obat di dapatkan 2 sampel penelitian (8,7\%). Obat didapatkan 1 sampel penelitian (4,3\%), Alergi makanan di dapatkan 14 sampel penelitian $(60,9 \%)$, Alergi cuaca dingin di dapatkan 5 sampel penelitian (21,7\%), Alergi spora didapatkan 1 sampel penelitian (4,3\%) sedangkan alergi debu di dapatkan 1 sampel penelitian (4,3\%) (Tabel 1).

Nilai prevalensi ratio (PR) pada faktor alergi obat bernilai 5,8 $(>1)$ yang artinya faktor alergi obat dapat meningkatkan kejadian Urtikaria. Nilai prevalensi ratio (PR) pada faktor alergi makanan bernilai 13,4 (> 1) yang artinya faktor alergi makanan dapat meningkatkan kejadian Urtikaria. Nilai prevalensi ratio (PR) pada faktor alergi cuaca bernilai 7,2 (> 1) yang artinya faktor cuaca dapat meningkatkan kejadian Urtikaria. Nilai prevalensi ratio $(\mathrm{PR})$ pada faktor alergi spora bernilai $0,8(<1)$ yang artinya faktor alergi spora dapat mengurangi kejadian Urtikaria. Nilai prevalensi ratio (PR) pada faktor alergi debu bernilai 1,4 (>1) yang artinya faktor alergi debu dapat meningkatkan kejadian Urtikaria (Tabel 2).

\section{PEMBAHASAN}

Pada penelitian ini umur sampel penelitian terbanyak yaitu pada kategori dewasa dengan besar presentase $(60,87 \%)$, hal ini sejalan dengan penelitian yang dilakukan oleh vella dkk (2013) dimana di dapatkan basil kategori umur Dewasa paling banyak (38,5\%). Prevalensi Urtikaria dapat terjadi pada semua jenis kelamin dan berbagai kelompok umur. Pada umumnya sering terjadi pada usia dewasa muda. Umur rata-rata pasien Urtikaria ialah 35 tahun, jarang dijumpai pada umur kurang dari 10 tahun atau lebih dari 60 tahun.

Berdasarkan jenis kelamin pada orang dewasa sampel penelitian terbanyak yaitu pada jenis kelamin perempuan $(78,3 \%)$, hal ini sejalan dengan penelitian yang dilakukan oleh Vella dkk tahun 2010 dimana di dapatkan hasil jenis kelamin perempuan paling banyak dengan persentase sebesar $(68,8 \%) .{ }^{5}$ Hasil studini ini juga didukung oleh studi sebelumnya yang dilakukan oleh Casano N dkk tahun 2016 dimana jenis kelamin perempuan memiliki perbandingan 2-4:1 dibandingkan dengan jenis kelamin laki-laki. ${ }^{6}$ Perbedaan seks ini berlaku untuk semua jenis urtikaria pada semua kelompok usia. Satu penjelasan yang mungkin bisa menjelaskannya, yaitu wanita memiliki kadar hormone estrogen dan progesterone yang lebih tinggi serta kadar hormon dehydroepiandrosterone sulfate (DHEA-S) yang rendah di bandingkan laki-laki dimana secara patogenesis mempengaruhi sekresi histamin pada sel mast. ${ }^{7}$

Berdasarkan hasil data sampel genetik penelitian terbanyak ada pada tidak ditemukan adanya faktor genetik (91,3\%). Menurut penelitian sebelumnya oleh Gimenez-Arnau A untuk faktor genetik jarang ditemukan dikarekan penyakit urtikaria akut lebih sering di sebabkan oleh faktor lingkungan atau kontak fisik. $^{8}$

Hasil penelitian terhadap pekerjaan diketahui bahwa jumlah terbanyak pada ibu rumah tangga $(34,8 \%)$. Hasil penelitian ini sejalan dengan 
penelitian yang dilakukan oleh Lezaun A dkk dimana didapatkan hasil ibu rumah tangga paling banyak terutama berhubungan dengan kontak terhadap nasi atau sereal lainnya. ${ }^{9}$ Dikarenakan ibu rumah tangga sering melakukan pekerjaan rumah yang bisa menularkan urtikaria melalui kontak fisik karena terpapar oleh bakteri maupun jamur.

Berdasarkan penyebab urtikaria akut terbanyak yaitu pada alergi makanan (56.5\%). Hasil studi ini sejalan dengan penelitian yang dilakukan oleh Chung BY dkk dimana didapatkan penyebab urtikaria akut adalah alergi makanan. ${ }^{10}$ Peranan makanan ternyata lebih penting pada urtikaria akut, umumnya akibat reaksi imunologik. Makanan berupa protein atau bahan yang lain seperti kacang kedelai, telur, gandum, dan keju yang dicampurkan ke dalamnya seperti zat warna, penyedap rasa atau bahan pengawet yang bisa menimbulkan gejala urtikaria akut. Contoh makanan yang sering menimbulkan urtikaria adalah ikan, kacang, telur, tomat, babi, keju, bawang dan semangka. ${ }^{11}$

\section{SIMPULAN}

Pada penelitian ini umur sampel penelitian terbanyak yaitu pada kategori umur Dewasa, diikuti dengan jenis kelamin perempuan, tidak adanya risiko genetik, kelompok pekerjaan ibu rumah tangga, dan penyebab alergi makanan. Berkaitan dengan hal tersebut maka perlunya penelitian lebih lanjut dilakukan dengan jumlah sampel yang lebih besar, variabel yang lebih banyak dan bervariasi hingga luas area penelitian yang lebih besar.

\section{KONFLIK KEPENTINGAN}

Tidak terdapat konflik kepentingan dalam penulisan artikel penelitian ini

\section{PERSETUJUAN ETIK}

Penelitian ini telah mendapat persetujuan etik sebelum penelitian dilakukan oleh Fakultas Kedokteran, Universitas Udayana, RSUP Sanglah, Bali, Indonesia dengan nomor Ethical Clearance (EC) adalah 2463/UN14.2.2.VII.14/LP/2018.

\section{PENDANAAN}

Penulis bertanggung jawab terhadap pendanaan penelitian ini tanpa melibatkan pihak sponsor, grant, atau sumber pendanaan lainnya.

\section{KONTRIBUSI PENULIS}

Seluruh penulis memiliki kontribusi yang sama dalam penulisan artikel penelitian ini baik dari tahap penyusunan proposal, konsep penelitian, pengambilan sampel, analisis data, hingga penyampaian hasil penelitian.

\section{DAFTAR PUSTAKA}

1. Sabroe RA. Acute urticaria. Immunol Allergy Clin North Am. 2014;34(1):11-21.

2. Schaefer P. Acute and Chronic Urticaria: Evaluation and Treatment. Am Fam Physician. 2017;95(11):717-724.

3. Deacock SJ. An approach to the patient with urticaria. Clin Exp Immunol. 2008;153(2): 151-161.

4. Jafilan L, James C. Urticaria and Allergy-Mediated Conditions. Prim Care. 2015;42(4):473-83.

5. Vella, Widiasmara D, Hutomo M. Urtikaria - Studi Retrospektif. Berkala Ilmu Kesehatan Kulit \& Kelamin. 2010;22(3):172-179

6. Cassano N, Colombo D, Bellia G, Zagni E, Vena GA. Gender-related differences in chronic urticaria. G Ital Dermatol Venereol. 2016;151(5):544-52.

7. Kasperska-Zajac A, Brzoza Z, Rogala B. Sex hormones and urticaria. J Dermatol Sci. 2008;52(2):79-86

8. Giménez-Arnau A. Contact urticaria and the environment. Rev Environ Health. 2014;29(3):207-15.

9. Lezaun A, Igea JM, Quirce S, Cuevas M, Parra F, Alonso MD, , et al. Asthma and contact urticaria caused by rice in a housewife. Allergy. 1994;49(2):92-5.

10. Chung BY, Cho YS, Kim HO, Park CW. Food Allergy in Korean Patients with Chronic Urticaria. Ann Dermatol. 2016;28(5):562-568.

11. Sanchez J, Sanchez A, Cardona R. Dietary Habits in Patients with Chronic Spontaneous Urticaria: Evaluation of Food as Trigger of Symptoms Exacerbation. Dermatol Res Pract. 2018; 2018: 6703052.

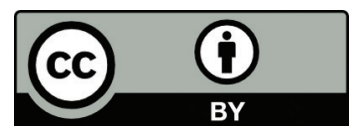

This work is licensed under a Creative Commons Attribution 